\title{
Gambaran kualitas pelayanan posyandu balita di wilayah kerja Puskesmas Umbulharjo I Yogyakarta
}

\author{
Dwi Astrini Wulandari ${ }^{1 *}$, Enny Fitriahadi ${ }^{2}$ \\ ${ }^{1,2}$ Program Studi Kebidanan Program Sarjana Terapan, Universitas 'Aisyiyah Yogyakarta-Indonesia
}

\begin{abstract}
Word Health Organization (WHO) states that every health care facility to improve maternal and infant health should have a service list of standards and quality statements. To determine the quality of maternal and children health unitsfor toddlers, 8 indicators have been developed to assess the service quality of maternal health units. Applied a descriptive design with a cross sectional approach. The sample size used 35 total sampling of under-fives. Univariate analysis was used as data analysis, and retrieving data used observation sheets. The results of the research on the distribution of the service quality of maternal and children health units showed that 8 those health units $(22.9 \%)$ were stable, and $27(77 \%)$ were not yet solid. The average cadre on duty showed $33(94.3 \%)>5$ people, and $2(5.7 \%)<5$ people. The frequency of weighing $>8$ times obtained 35 (100\%). The average D/S coverage obtained $27(77.1 \%) \mathrm{D} / \mathrm{S}<50 \%, 2(5.7 \%) \mathrm{D} / \mathrm{S}=50 \%$, and $6(17.4 \%) \mathrm{D} / \mathrm{S}<50 \%$. Cumulative coverage of Maternal and Children Health Bookshowed $17(48.6 \%)>50 \%$, $1(2.8 \%)=50 \%$, and $17(48.6 \%)<50 \%$. Cumulative coverage of Family Planning reached $25(71.4 \%)>50 \%$, $3(8.6 \%)=50 \%$,and $7(20 \%)<50 \%$. Cumulative immunization coverage obtained $20(11.1 \%)>50 \%$ and $15(42.9 \%)<50 \%$. Theadditional programs showed $25(71.4 \%)$, and $10(28.6 \%)$ had no additional programs. There were $28(80 \%)$ healthy funds, and $7(20 \%)$ got no funds. Recording and reporting as well as the activity archive and management of task division should be further enhanced to improve the service quality of maternal and children health unit including coordination across sectors or stakeholders.
\end{abstract}

Keywords: toddler; service quality of maternal and children health unit

Word Health Organization (WHO) setiap fasilitas pelayanan kesehatan untuk peningkatan kesehatan ibu dan bayi memiliki pelayanan daftar standar dan pernyataan kualitas. Untuk mengetahui kualitas pelayanan posyandu balita, telah dikembangkan 8 indikator penilaian kualitas pelayanan posyandu. Penelitian ini menggunakan desain deskriptif dengan pendekatan cross sectional. Besar sampel yang digunakan sebanyak 35 posyandu balita berstatus belum mantap (total sampling). Analisis data menggunakan analisis univariat. Pengambilan data dengan menggunakan lembar observasi. Hasil penelitian distribusi kualitas pelayanan posyandu balita adalah 8 Posyandu balita (22,9\%) mantap dan $27(77, \%)$ belum mantap. Rerata kader tugas $33(94,3 \%)>5$ orang, dan $2(5,7 \%)<5$ orang. Frekuensi penimbangan $>8$ kali ada $35(100 \%)$. Rerata cakupan D/S 27 (77,1\%) D/S <50\%, D/S =50\% ada 2 (5,7\%), 6 (17,4\%) D/S <50\%. Cakupan kumulatif KIA 17 (48,6\%) $>50 \%,=50 \%$ ada $1(2,8 \%)<50 \%$ ada 17 (48,6\%). Cakupan kumulatif KB $25(71,4 \%)>50 \%,=50 \%$ ada $3(8,6 \%)$ dan 7 (20\%). <50\%. Cakupan kumulatif imunisasi $20(11,1 \%)>50 \%$, dan $15(42,9 \%)<50 \%$. Ada program tambahan $25(71,4 \%)$ dan $10(28,6 \%)$ tidak ada program tambahan. Ada dana sehat $28(80 \%)$ dan tidak ada 7 (20\%). Pencatatan dan pelaporan kemudian arsip kegiatan, managemen pembagian tugas harus lebih ditingkatkan untuk peningkatan kualitas pelayanan posyandu antara lain koordinasi lintas sektor ataupun kepada pihak pemangku kepentingan (stakeholder).

Kata Kunci: balita; kualitas pelayanan posyandu 
*Corresponding Author: Dwi Astrini Wulandari (email: dwiwuland12@gmail.com) 


\section{Pendahuluan}

Promosi kesehatan menurut World Health Organization (WHO) di definisikan merevitalisasi pendidikan dengan istilah promosi kesehatan, kalau pendidikan kesehatan diartikan sebagai upaya perubahan perilaku, maka promosi kesehatan tidak hanya untuk perubahan perilaku, tetapi juga disamping itu promosi kesehatan lebih menekankan pada peningkatan kemampuan hidup sehat, bukan sekedar berperilaku sehat (WHO, 2016).

Standar kualitas pelayanan fasilitas kesehatan untuk meningkatkan kesehatan ibu dan bayi terdiri dari 8 domain yang harus di ukur atau dinilai Standar di pusatkan pada wanita, ibu bersalin, bayi baru lahir dan keluarga yang dirancang untuk mengatasi prioritas yang diindentifikasi sebagai penyebab utama kematian ibu dan bayi yaitu : 1) Setiap wanita dan bayi menerima perawatan rutin; 2) Sistem informasi kesehatan sebagai mamastikan penangganan dini dan tepat sebagai peningkatan pelayanan wanita dan bayi; 3) Kondisi wanita dan bayi yang tidak dapat ditangani secara efektif dilakukan rujuk dengan tepat; 4) Komunikasi secara efektif dalam menanggapi kebutuhan dan preferensi: 5) wanita dan bayi menerima pelayanan dengan hormat dan menjaga privasi; 6) keluar dapat memberikan dukungan emosional 7) Staff yang kompeten secara konsisten dalam memberi pelayanan kesehatan rutin dan mengelola komplikasi; 8) memiliki fasilitas kesehatan lingkungan fisik yang sesuai, dengan persediaan air, sanitasi dan energi yang memadai, obat-obatan, persediaan dan peralatan untuk perawatan ibu dan bayi baru lahir yang rutin dan manajemen komplikasi (WHO, 2017)

Negara Washington memiliki 6 standar ukuran kualitas di pusat kesehatan masyarakat yaitu : 1) kontrol diabetes dengan standar penilaian $\mathrm{HbA} 1 \mathrm{c}<7 \%$ dan $>9 \%$; 2) kontrol hipertensi dengan tekanan darah $<140 / 90$ mmHg; 3) kesehatan wanita dengan usia 2464 yang menerima tes papsmer dalam 3 tahun terakhir; 4) kesehatan anak dengan usia 2 tahun sepenuhnya diimunisasi; 5) persalinan; 6) perawatan prenatal tepat waktu (Kruk et al., 2017)

Kementrian Kesehatan Rl, 2017 mengemukakan bahwa untuk mengetahui kualitas pelayanan posyandu balita dapat diukur melalui kualitas pelayanan posyandu balita yang terdiri dari mantap dan belum mantap.

Untuk meningkatkan kualitas pelayanan posyandu balita di Indonesia ditetapkan 
seperangkat indikator yang digunakan sebagai penyaring yang terdiri dari; 1) rerata kader tugas dengan jumlah standar kader 5 orang atau lebih; 2) frekuensi penimbangan batasanya $>8$ kali; 3) rerata cakupan D/S jumlah balita diwilayah kerja posyandu (D) terhadap partisipasi balita dalam pelaksanaan posyandu balita (S); 4) cakupan kumulatif yakni jumlah partisipasi ibu dan anak dalam pelaksaan program KIA; 5) cakupan kumulatif KB dianggap baik bila tercapai <50 \%; 6) cakupan kumulatif imunisasi jumlah bayi/balita diwilayah kerja posyandu balita terhadap partisipasi bayi/balita dalam pelaksanaan program; 7) program tambahan kegiatan tambahan disamping kegiatan utama; 8) cakupan dana sehat > 50\% (Kementrian Kesehatan RI, 2017a)

Di Negara maju New Zealand memiliki program yang hampir sama dengan Indonesia yaitu bernama Plunket, Planket berdiri dibawah naungan departemen kesehatan di Sleandia Baru sejak tahun 1907.

Pada tahun 2017, jumlah posyandu di Indonesia adalah sebanyak 294.428 posyandu dan sebanyak 169.087 atau sekitar 57,43\% posyandu merupakan posyandu aktif.

WHO, 2016 tingkat kematian balita secara global menurun sebesar 56\% dari 93 kematian per 1000 kelahiran hidup pada tahun 1990 menjadi 39 per seribu pada tahun 2017. Sekitar 73\% kematian balita terjadi di dua wilayah pada tahun 2017 WHO wilayah Afrika 49\% dan WHO di wilayah Asia selatan 24\%. Menurut profil kesehatan DIY tahun 2012 menyebutkan bahwa AKBA DIY adalah 9,8 per 1000 kelahiran hidup. Kasus kematian balita di DIY juga flukuatif dari tahun 2012-2017, tetapi pada kurun 4 tahun terakhir mengalami penurunan yaitu 454 pada tahun 2014 dan turun menjadi 378 pada tahun 2015, turun lagi menjadi 323 pada tahun 2016. Hal ini menunjukan bahwa DIY telah memenuhi target pemerintah Indonesia (32 per 1000 kelahiran hidup) namun pada tahun 2017 menjadi 343, kota Yogyakarta untuk pada tahun 2016 ada 30 kasus kematian bayi dan balita namun pada tahun 2017 kembali mengalami peningkatan yaitu terdapat 33 kasus kematian Balita (Kementrian Kesehatan Rl, 2017b).

Peran bidan dalam memberikan pelayanan kesehatan anak sebagaimana dimaksud pada ayat (1) bidan berwenang melakukan c pemantauan tumbuh kembang bayi, anak balita dan anak prasekolah sebagaimana diatur di Permenkes RI No. 28 Tahun 2017 bagian kedua Kewenangan pasal 20 ayat 2 (Peraturan Menteri Kesehatan, 2017). 
Peran serta masyarakat adalah segala upaya fasilitas yang bersifat persuasif dan tidak memerintah, yang bertujuan untuk meningkatkan pengetahuan, sikap, perilaku dan kemampuan masyarakat dalam menemukan, merencanakan dan memecahkan masalah (Sari \& Indarwati, 2012)

Studi yang dilakukan Ariyani, et al., 2012 bahwasanya adanya keterbatasan dari petugas posyandu serta sarana dan prasarana di posyandu menyebabkan pelaksaan posyandu belum sesuai, hal ini menyebabkan menurunnya motivasi berkunjung ibu balita yang disebabkan kurangnnya mutu pelayanan pada saat posyandu.

Berdasarkan studi pendahuluan yang dilakukan di Dinas Kesehatan Yogyakarta diperoleh jumlah posyandu balita dari bulan Januari- Desember 2018 di wilayah kerja Puskesmas Umbulharjo । berjumlah 55 posyandu balita yang berstatus belum mantap (pratama) 35 Posyandu balita dengan mempunyai program pokok yakni perbaikan gizi masyarakat, perbaikan gizi balita, program kesehatan ibu dan anak, program KB, program Imunisasi dan program penganggulangan diare. Pernyataan oleh salah seorang petugas puskesmas mengatakan bahwa masih terkendala dengan kelengkapan standarisasi posyandu balita yaitu sarana penimbangan yang kurang nyaman, dan partisipasi masyarakat yang kurang disebabkan sebagian ibu-ibu bekerja.

\section{Metode}

Metode penelitian adalah Penelitian ini menggunakan desain deskriptif dengan pendekatan cross sectional. Besar sampel yang digunakan sebanyak 35 posyandu balita berstatus belum mantap (total sampling). Analisis data menggunakan analisis univariat. Pengambilan data dengan menggunakan data sekunder Puskesmas Umbulharjo I Yogyakarta dengan menggunakan lembar observasi.

Tabel 1. Distribusi Kualitas Pelayanan Posyandu Balita Berdasarkan Indikator Kualitas Pelayanan Posyandu Balita Januari-Desember 2018

\begin{tabular}{ccc}
\hline \multicolumn{1}{c}{ Karakteristik } & Frekuensi $(\mathrm{n}=35)$ & Presentase $(\%)$ \\
\hline Rerata Kader Tugas & & \\
a. $>5$ & 33 & 94,3 \\
b. $\quad=5$ & 0 & 0 \\
c. $\quad<5$ & 2 & 5,7 \\
Frekuensi Penimbangan & & \\
a. $>8$ & 35 & 100 \\
b. $\quad=8$ & 0 & 0 \\
\hline
\end{tabular}




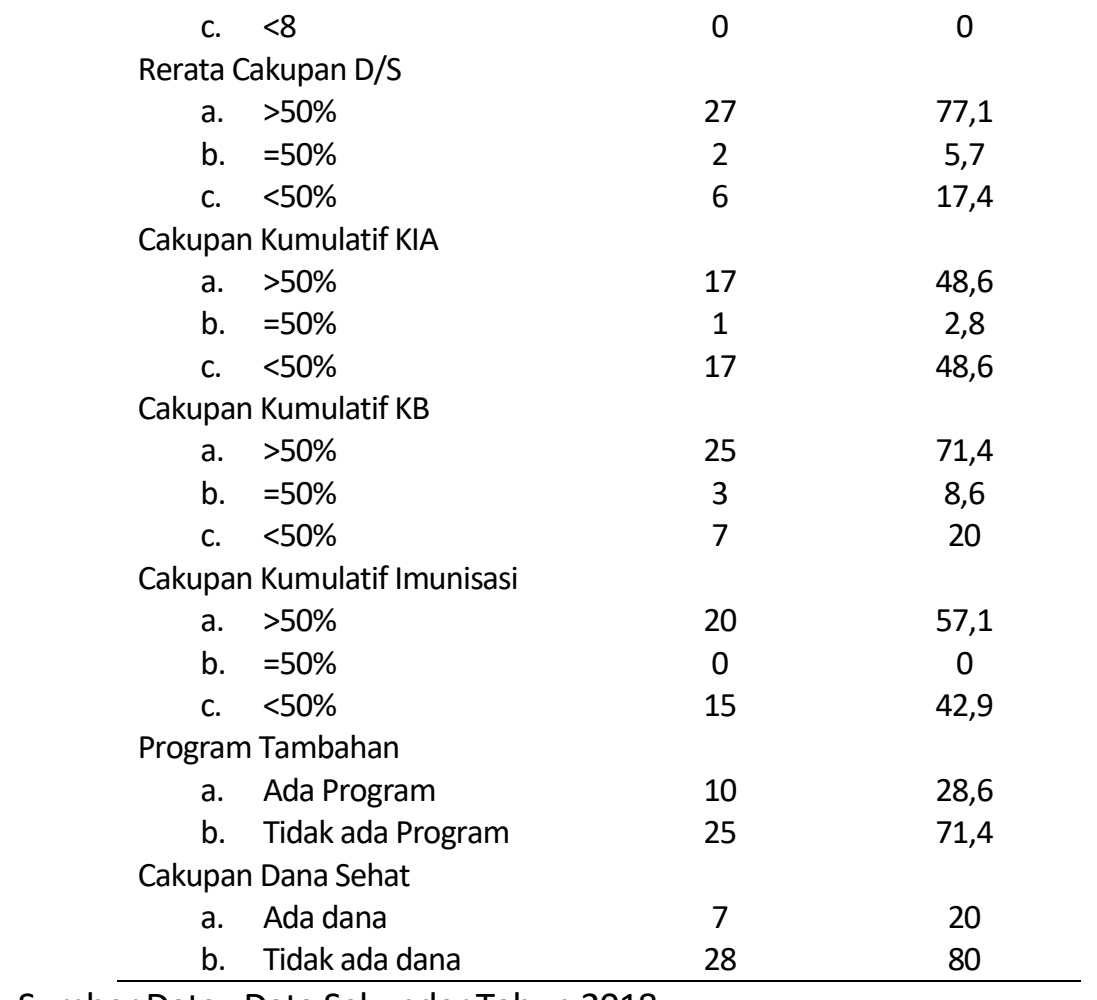

Sumber Data : Data Sekunder Tahun 2018

\section{Hasil dan pembahasan}

1. Karakteristik Objektif Distribusi Kualitas

Pelayanan Posyandu Balita

Diketahui bahwa karakteristik responden sebagian besar rerata kader tugas $>533$ (94,3\%), Frekunesi penimbangan >8 (100\%), rerata cakupan D/S $>50 \%$ sebanyak 27 (77,1\%), cakupan kumulatif KIA > 50\% ada 17
(48,6\%) dan <50\% ada 17 (48,6\%), cakupan kumulatif $K B>50 \%$ sebanyak $25(71,4 \%)$, cakupan kumulatif imunisasi $>50 \%$ ada 20 (57,1\%), program tambahan ada $10(28,6 \%)$, dan cakupan dana sehat tidak ada sebanyak 28 (80\%).

Tabel 2. Distribusi Kualitas Pelayanan Posyandu Balita.

\begin{tabular}{lcl}
\hline Kualitas Pelayanan Posyandu & $F(n=35)$ & $\%$ \\
\hline Mantap & 8 & $22,9 \%$ \\
Belum Mantap & 27 & $77,1 \%$ \\
Jumlah & 35 & $100 \%$ \\
\hline
\end{tabular}

Sumber Data : Data Sekunder Tahun 2018 
Berdasarkan Tabel 2 Distribusi frekuensi menunjukan bahwa kualitas pelayanan posyandu balita didapatkan ada 8 (22,9\%) posyandu berstatus mantap dalam hal ini telah mampu melaksanakan kegiatan utamanya secara rutin setiap bulan dengan cakupan masing-masing $\geq 50 \%$ dan telah melakukan kegiatan tambahan. Ada 27 (77,1\%) posyandu berstatus belum mantap dalam hal ini kegiatan dalam kurun satu tahun terakhir belum terlaksana secara rutin, serta jumlah kader sangat terbatas $>5$ orang.

a. Kualitas Pelayanan Posyandu Balita di Posyandu Balita Wilayah Kerja Puskesmas Umbulharjo I Yogyakarta.

Masalah-masalah kesehatan seperti gizi dipengaruhi oleh rendahnya pemanfaatan dan kualitas pelayanan posyandu. Kegiatan posyandu hanya terkesan sebagai kegiatan rutinitas penimbangan balita, dan pemberian imunisasi, sementara penggerakkan aksi masyarakat dan komunikasi hampir tidak ada. Sehinggah masyarakat belum sepenuhnya menjadikan posyandu sebagai pusat kegiatan kesehatan masyarakat. Hal ini bisa disebabkan karena kurangnya kemampuan kader kesehatan dalam mengelola dan meningkatkan kualitas pelayanan kesehatan posyandu.
Berdasarkan hasil penelitian menyimpulkan bahwa tingkat partisipasi masyarakat dalam mengikuti kegiatan posyandu masih rendah. Intervensi yang dapat dilakukan untuk perbaikan tingkat adalah meningkatkan cakupan dengan mengikut sertakan tokoh masyarakat sebagai motivator serta lebih menggiatkan kader dalam mengelola kegiatan posyandu balita (Kemenkes RI, 2011).

Hasil penelitian ini berbeda dengan penelitian yang dilakukan oleh Bintanah (2014), yang menemukan sebagian besar $(86,7)$ posyandu balita wilayah kerja Puskesmas Halmahera Kota Semarang berstrata mandiri. Menurut Kemenkes RI (2011), dengan era modernisasi seperti saat ini seyogyanya dapat diikuti dengan perkembangan dalam bidang pelayanan kesehatan sehingga dapat terjadi kesinambungan.

Masalah terkait dengan mutu layanan di posyandu, terlihat dari rendahnya kedatangan balita ke posyandu, hasil observasi dilapangan menunjukkan bahwa rendahnya kedatangan balita ke posyandu di picu adanya trauma yang dirasakan oleh keluarga (ibu) balita setiap kali kunjungan posyandu, disebakan rasa tidak nyaman selama proses penimbangan, karena faktor peralatan timbang yang kurang nyaman (Wahyuni \& Hanum, 2018). 
b. Rerata Kader Tugas di Posyandu Balita Wilayah Kerja Puskesmas Umbulharjo I Yogyakarta.

Berdasarkan Tabel 1 data rerata kader sebagian besar $>5$ orang atau diatas lima orang yaitu sebanyak $33(94,3 \%)$ dan diikuti $<5$ orang atau dibawah lima orang yaitu $2(5,7 \%)$

Negara New Zealand terdapat program yang hampir sama dengan posyandu balita yang ada di Indonesia yaitu dengan nama Plunket, $\mathrm{Na-}$ mun hal yang berbeda dilakukan oleh departemen kesehatan New Zealand untuk pelaksaan komunitas masyarakat, pelaksanaan Plunket dilaksanakan dua minggu sekali dengan dilakukan oleh perawat terlatih atau bersertifikat sedangkan di Indonesia pelaksanaan posyandu dilakukan oleh kader-kader terlatih, hal ini dilakukan untuk mendukung perkembangan, kesehatan dan kesejahteraan anak-anak di bawah 5 tahun (Langer et al., 2014).

Bedah halnya kader di posyandu kadang harus berganti dan perekrutan baru tenaga kader, karena tidak semua kader bisa bertahan lama alasanya bisa karena tidak memiliki waktu intens yang cukup, berpindah tempat tinggal dan faktor usia.

Kegiatan posyandu sangat tergantung pada kader posyandu, keberadaan kader posyandu dibutuhkan sebagai salah satu sistem penye- lenggaraan pelayanan kebutuhan kesehatan dasar. Kader posyandu merupakan ujung tombak pelayanan kesehatan yang merupakan kepanjangan tangan puskesmas. Ada 7 kriteria yang harus dipenuhi oleh seorang kader seperti tercantum dalam instruksi menteri dalam negeri no. 0 tahun 1990 tentang peningkatan pembinaan mutu posyandu yakni : (1) Dapat membaca dan menulis; (2) Berjiwa sosial dan mau berkerja sama secara relawan; (3) mengetahui adat istiadat serta kebiasaan masyarakat; (4) Mempunyai waktu yang cukup; (5) Bertempat tinggal diwilayah posyandu; (6) Berpenampilan ramah dan simpatik; dan (7) Diterima masyarakat setempat (Simanjuntak, 2015).

b. Frekuensi Penimbangan di Posyandu Balita Wilayah Kerja Puskesmas Umbulharjo I Yogyakarta.

Berdasarkan tabel 4.1 data frekuensi penimbangan sebagian besar $>8$ atau 8 kali dalam posyandu yaitu ada $35(100 \%)$, frekuensi penimbangan $=8$ atau 8 kali dalam setahun yaitu 0 (0\%) dan frekunesi penimbangan $<8$ atau lebih dalam 8 kali dalam setahun yaitu $0(0 \%)$. Hal ini menunjukan bahwa reponden dalam penelitian mempunyai frekunesi penimbangan tergolong lebih dari $>8$ kali dalam kurun waktu satu tahun terakhir. 
Ibu balita dengan pengetahuan kurang namun memiliki frekuensi penimbangan balita cukup dapat dikaitkan dengan faktor lain dimana faktor tersebut membentuk perilaku tanpa dilandasi pengetahuan terlebih dahulu yaitu jarak tempat tinggal dan dukungan keluarga. Jarak tempat tinggal ibu ke posyandu yang dekat, sehinggah memudahkan ibu untuk berkunjung ke posyandu pada saat hari pelaksanaan posyandu. Adanya dukungan kelurga dari pihak suami maupun keluarga lainnya dapat memotivasi ibu untuk secara rutin ke posyandu. Ibu balita dengan sikap negatif namun memiliki frekuensi penimbangan balita cukup dapat dikaitkan dengan faktor lain seperti pengaruh teman sebaya dan dukungan keluarga. Adanya pengaruh oleh teman sebaya yang mengajak untuk aktif ke posyandu, sehinggah adanya semangat tersendiri karena memiliki rekan untuk bersama-sama pergi ke posyandu (Pristiani et al., 2016).

Nigeria tepatnya di Negara Afrika Bagian barat, salah satu masalah utama yang mungkin bertanggung jawab atas pengetahuan yang buruk adanya kurangnya pelatihan ulang oleh tenaga pekerja komunitas kesehatan masyarakat. Bahwannya karena pengetahuan yang buruk dalam penyampaian informasi keteraturan dan prosedur penimbangan untuk anak usia 1-2 tahun dan 2-5 tahun masing-masing belum mengetahui intervensi yang diperlukan. Tenaga pekerja komunitas kurangnya pemahaman dalam memberikan informasi atau nasehat untuk perbaikan awal jika terjadi perubahan berat badan pada balita (Dewi S. et al., 2013).

Hasil analisis penelitian yang dilakukan oleh Pristiani (2016), menunjukan bawah ibu balita dengan status bekerja memiliki frekuensi penimbangan balita yang cukup sebesar $54,8 \%$ dan memiliki frekuensi penimbangan balita yang kurang sebesar $45,2 \%$. Sedangkan ibu balita dengan status tidak bekerja memiliki frekuensi penimbangan balita yang cukup sebesar $76,8 \%$ dan memiliki frekuensi penimbangan balita yang kurang sebesar $23,3 \%$.

c. Cakupan Kumulatif D/S di Posyandu Balita Wilayah Kerja Puskesmas Umbulharjo I Yogyakarta.

Berdasarkan Tabel 1 data rerata cakupan D/S sebagian besar $>50 \%$ yaitu ada $27(77,1 \%)$, rerata cakupan $\mathrm{D} / \mathrm{S}=50 \%$ terdapat $2(5,7 \%)$ dan rerata cakupan $D / S<50 \%$ yaitu terdapat 6 $(17,4 \%)$.

Ada juga karena faktor lokasi ibu yang memiliki balita yang tempat tinggalnya sejauh 1,5 sampai $2 \mathrm{~km}$ dan kondisi jalan menuju lokasi posyandu cukup jauh. Ibu yang memiliki kendaraan rutin datang ke posyandu setiap bulan. 
Sementara ibu yang memiliki kendaraan motor hanya sekali dalam dua bulan datang ke posyandu. Adapun alasan mereka jarang datang posyandu adalah kadang punya ongkos kadang tidak, ada rasa khawatir, cenderung merasa tidak perlu lagi ke posyandu setelah anak diimunisasi pada usia tiga tahun (Esamai et al., 2017).

Faktor penyebab lainnya pengalaman masa lalu, kebiasaan atau pengalaman masa lalu membuat ibu-ibu tersebut tidak mengikuti atau tidak ikut berpartisipasi dalam pelayanan posyandu balita, karena dari dulu banyak ditemukan atau banyak yang terjadi pada anakanak mereka bahwa setelah pulang dari posyandu anak mereka malah menjadi sakit, sehinggah keluarga baik itu suami atau orang tua melarang membawa balita ke posyandu (Rahayu et al., 2017).

Menurut penelitian Rahayu et al., 2017 kegiatan posyandu tidak aktif, kegiatan posyandu tidak berkembang sehinggah masyarakat

menjadi bosan atau malas datang ke posyandu karena ke posyandu hanya datang menimbang berat badan bayi, imunisasi setelah ibuibu yang datang membicarakan hal yang lain dan anak-anak berlari-lari disaat posyandu dilaksanakan, sehinggah ibu tersebut malas untuk berpartisipasi selanjutnya dan ini juga bisa di karenakan tempat pelaksanaan posyandu juga tidak efesien.

d. Cakupan Kumulatif KIA di Posyandu Balita Wilayah Kerja Puskesmas Umbulharjo I Yogyakarta.

Berdasarkan tabel 1 data Cakupan kumulatif KIA sebagian besar $>50 \%$ yaitu ada $17(48,6, \%)$, cakupan kumulatif $\mathrm{KIA}=50 \%$ terdapat $1(2,8 \%)$ dan cakupan kumulatif KIA $<50 \%$ yaitu terdapat $17(48,6 \%)$.

Peru merupakan negara berpenghasilan menengah kebawah, negara yang memiliki program kesehatan yang kurang berhasil dibidang kesehatan ibu. Layanan kesehatan yang masih mengikuti tradisi dan praktik budaya dimana untuk pelayanan kesehatan ibu dan anak dilakukan dibawah bimbingan dukun bayi tradisonal dibanding memilih fasilitas kesehatan yang telah disediakan (United Nations Children's Fund (UNICEF), 2004).

Rendahnya cakupan kumulatif KIA disebabkan kurangnya sarana dan prasarana, serta masyarakat yang lebih memilih langsung ke puskesmas untuk memeriksakan kesehatannya. Salah satu petugas kesehatan puskesmas menyatakan posyandu balita diwilyah kerja Puskesmas Umbulharjo I mempunyai kegiatan penimbangan, imunisasi dan pemberian makanan tambahan, sekali-kali juga diberi 
penyuluhan. Namun, untuk kegiatan seperti pemeriksaan ibu hamil, ibu bersalin dan nifas, petugas mengarahkan langsung ke puskesmas karena kurangnya sarana prasarana yang ada di posyandu balita. Hal yang sama di Negara Afganista, ada kesenjangan sosial ekonomi dan regional dapat menjadi ancaman untuk mencapai kemajuan kesehatan, masyarakat yang berpenghasilan tinggi atau orang kaya lebih memilih melakukan pelayanan kesehatan ibu dan anak di rumah sakit dibandingkan dengan pelayanan komunitas berbasis masyarakat (Akseer et al., 2016).

Hasil penelitian Anne Austin dkk (2014),di Negara Afrika Kualitas perawatan berbasis fasilitas untuk ibu dan bayi merupakan salah satu faktor utama tingkat tinggi morbiditas dan mortalitas, wanita yang selamat dari persalinan, sekitar 10 juta akan mengalami komplikasi, banyak dari kondisi dan kematian ini disebabkan karena pelayanan di komunitas yang tidak tepat waktu, efektif dan terjangkau.

e. Cakupan Kumulatif KB di Posyandu Balita Wilayah Kerja Puskesmas Umbulharjo I Yogyakarta.

Berdasarkan Tabel 1 data cakupan kumulatif KB sebagian besar $>50 \%$ yaitu ada $25(71,4 \%)$, cakupan kumulatif $\mathrm{KB}=50 \%$ terdapat $3(8,6 \%)$ dan cakupan kumulatif $K B<50 \%$ yaitu terdapat $7(20 \%)$.

Berdasarkan data Riskesdas (2012), posyandu balita bukan pilihan utama bagi PUS/WUS untuk mendapatkan pelayanan KB. PUS/WUS lebih memilih untuk ke tempat pelayanan kesehatan lainnya seperti bidan praktek dan puskesmas. Hal ini terjadi karena masih kurangnya sarana dan prasarana yang memadai untuk dilakukan pelayanan KB di posyandu balita. Selain itu, kurangnya sosialisasi tentang manfaat ber KB oleh petugas kesehatan dan kader posyandu turut mempengaruhi PUS/WUS untuk mendapatkan pelayanan KB diposyandu balita.

Pendahuluan kebutuhan akan KB yang belum terpenuhi akan ber KB pada penggunakaan kontrasepsi yang masih rendah. Total kebutuhan yang belum terpenuhi untuk KB di Malawi diantara WUS diperkirakan $18,5 \%$ dan PUS diperkirakan 25\%. Buruknya akses berbasis kesehatan masyarakat terdekat untuk ber KB dan kurangnya ketersediaan yang diinginkan. Faktor penyebab lainnya kebutuhan ber KB yang belum terpenuhi, yaitu kurangnya keterlibatan pria dalam ber KB, mitos dan kesalah pahaman tentang $\mathrm{KB}$, akses yang buruk ke fasilitas kesehatan, kurangnya ketersediaan metode KB (Lemani et al., 2016). 
Hasil penelitian yang hampir sama oleh Muthiah dan Kadarisman (2013), didapatkan lebih dari setengah PUS $(58,59 \%)$ tidak mengikuti program KB. Tingginya PUS yang tidak ber KB disebabkan tidak memiliki biaya, serta masyarakat juga belum dapat terlepas dari budaya "banyak anak, banyak rezeki”. Padahal banyak anak akan mengeluarkan biaya lebih banyak sehingga mempengaruhi kesejahteraan keluarga.

f. Cakupan Kumulatif Imunisasi di Posyandu Balita Wilayah Kerja Puskesmas Umbulharjo I Yogyakarta.

Berdasarkan Tabel 1 data cakupan kumulatif imunisasi sebagian besar $>50 \%$ yaitu ada 20 $(11,1 \%)$, cakupan kumulatif imunisasi $=50 \%$ terdapat $0(0 \%)$ dan cakupan kumulatif imunisasi $<50 \%$ yaitu terdapat $15(42,9 \%)$.

Penyebab rendahnya cakupan kumulatif imunisasi diwilayah kerja Umbulharjo I memang belum diketahui secara pasti. Namun, menurut Kemenkes RI (2013), rendahnya cakupan kumulatif imunisasi di posyandu balita tidak terlepas dari petugas kesehatan dan peran kader posyandu balita.

Negara Arbegona, Ethiopia Selatan dalam penelitian Leida I.M., 2010 faktor penyebab cakupan imunisasi rendah diwilayah tersebut mobilisasi masyarakat atau imigrasi satu tempat ke tempat yang lain ibu sehinggah tidak dapat menyelesaikan imunisasi secara lengkap. Sehinggah para petugas kesehatan sulit untuk melacak ibu tersebut sehinggah kemungkinan tidak menyelesaikan imunisasi anak mereka, selain itu kurangnya pengetahuan kepatuhan keluarga atau ibu tentang manfaat imunisasi, sehinggah hanya mengetahui tentang efek samping vaksin yang umum, jadwal imunisasi yang tidak sesuai dengan jadwal kesibukkan ibu.

Penelitian ini mengindetifikasi tentang faktor yang mempengaruhi anak tidak imunisasi di Bangladesh, adapun faktor yang berpengaruh siginifikan yaitu usia, pendidikan, status kerja para ibu, kesadaran akan ke klinik komunitas, status penghasilan dan variasi geografis. Faktorfaktor penyebabnya seperti pengangguran ibu status sosial ekonomi yang rendah secara signifikan menemukan anak-anak dari ibu yang menganggur gagal menerima vaksinasi tepat waktu alasannya di Bangladesh sebagian wanita pengangguran sepenuhnya terlibat dalam pekerjaan domestik dan pekerjaan tidak dibayar, karena mereka cenderung melupakan waktu vaksinasi anak-anak mereka. Hal ini bisa dikatakan anak yang tinggal di strata sosial ekonomi rendah gagal memanfaatkan imunisasi di pelayanan kesehatan berbasis masyarakat atau komunitas. Faktor penyebab lainnya 
menunjukan pendidikan dan usia ibu. Anakanak dari ibu yang usianya lebih muda dan kurang berpendidikan lebih tidak memiliki vaksinasi lengkap dan kunjungan ke pelayanan kesehatan lebih rendah (Sheikh et al., 2018).

g. Program Tambahan di Posyandu Balita Wilayah Kerja Puskesmas Umbulharjo । Yogyakarta.

Berdasarkan Tabel 1 data program tambahan sebagian besar ada program tambahan yaitu ada 25 (71,4\%), dan tidak ada cakupan program tambahan yaitu terdapat $10(28,6 \%)$.

Negara Afrika Selatan memiliki program tambahan yaitu pemberian pengobatan TB program ini dijalankan oleh pelayanan komunitas kesehatan hal ini dilakukan untuk menghemat biaya kepada masyarakat yang terkena TB tanpa perlu melakukan pengobatan di rumah sakit. Namun selama menjalankan program adapaun hambatan utama yaitu partisipasi masyarakat di negara berkembang adalah keinginan untuk mendapatkan imbalan relawan. Ada bukti yang menunjukan bahwa tidak adanya intensif para relawan dalam menjalan program cenderung rendah (Kruk et al., 2017).

Hasil penelitian ini berbeda dengan penelitian Dewi S. et al., 2013 di Kelurahan Lamper Lor Kota Semarang dimana posyandu balita mampu mengintegrasikan PAUD dan BKB. Namun, penerapan PAUD dan BKB tidak berjalan dengan maksimal karena posyandu balita jarang mengikut sertakan kedalam kegiatannya.

Menurut Kementrian Kesehatan RI, 2017a untuk meningkatkan keterpaduan antara posyandu balita, PAUD dan BKB, perlu dilakukan identifikasi dan penjajakan pada potensi dan kebutuhan masyarakat yang peduli terhadap pelayanan kesehatan, pengasuhan, dan pendidikan anak usia dini, sehingga dapat menciptakan keterpaduan dan pelayanan yang lengkap dan utuh antara posyandu balita, PAUD dan BKB.

h. Cakupan Dana Sehat di Posyandu Balita Wilayah Kerja Puskesmas Umbulharjo I Yogyakarta.

Berdasarkan tabel 1 data Cakupan dana sehat sebagian besar Tidak ada cakupan dana sehat yaitu ada 28 (80\%), dan cakupan dana sehat yaitu terdapat 7 (20\%).

\section{Kesimpulan}

Terdapat 8 Posyandu balita (22,9\%) berstrata atau dikategorikan mantap dan $27(77, \%)$ posyandu balita berstrata atau dikategorikan dikategorikan posyandu balita belum mantap, cakupan program utamanya (cakupan KIA, KB, 
dan Imunisasi) masih rendah yaitu kurang dari 50\%. Pemanfaatkan sumber daya sangat diperlukan untuk peningkatan kualitas pelayanan posyandu antara lain koordinasi lintas sektor ataupun kepada pihak pemangku kepentingan (stake holder). Mekanisme dan pembagian kerja lebih sistematis dan sesuai dengan bidangnya masing-masing tujuannya lebih mempermudah dalam pelaksanaan teknis dilapangan.

\section{Daftar Pustaka}

Akseer, N., Bhatti, Z., Rizvi, A., Salehi, A. S., Mashal, T., \& Bhutta, Z. A. (2016). Coverage and inequalities in maternal and child health interventions in Afghanistan. BMC Public Health, 16(Suppl 2).

Ariyani, R. D., Susanti, R., \& Mardianingsih, E. (2012). Faktor yang Berhubungan dengan Frekuensi Penimbangan Balita di Posyandu. Jurnal Keperawatan Soedirman, 7(3), 166-173.

Dewi S., A. C., Zahraini, D. A., \& Sabarini, S. (2013). Desain Pengembangan Anak Usia Dini Holistik Integratif PAUD Non Formal (Penelitian Research and Development di Pos PAUD Mutiara Kelurahan Lamper Lor Kecamatan Semarang Selatan). Jurnal Penelitian PAUDIA, 2(1), 105-126.

Esamai, F., Nangami, M., Tabu, J., Mwangi, A., Ayuku, D., \& Were, E. (2017). A system approach to improving maternal and child health care delivery in Kenya: Innovations at the community and primary care facilities (a protocol). Reproductive Health, 14(1), 1-18.

Kementrian Kesehatan RI. (2017a). Data Puskesmas 2017.
Kementrian Kesehatan RI. (2017b). Profil Kesehatan Indonesia RI 2017.

Kruk, M. E., Chukwuma, A., Mbaruku, G., \& Leslie, H. H. (2017). Variation de la qualité des services de soins primaires au Kenya, au Malawi, en Namibie, en Ouganda, en République-Unie de Tanzanie, au Rwanda et au Sénégal. Bulletin of the World Health Organization, 95(6), 408-418.

Langer, A., Salam, R. A., Lassi, Z. S., Link, C., Austin, A., Langer, A., Salam, R. A., Lassi, Z. S., Das, J. K., \& Bhutta, Z. A. (2014). Approaches to improve the quality of maternal and newborn health care : an overview of the evidence The Harvard community has made this article openly available. Please share how this access benefits you . Your story matters. Approaches to improve the q. Reproductive Health, 11(Suppl 2), S1.

Leida I.M. (2010). Faktor Risiko Kegagalan Konversi pada Penderita Tuberkulosis BTA Positif Baru. Media Kesehatan Masyarakat Indonesia, 6(3), 136-140.

Lemani, C., Tang, J., Kopp, D., Phiri, B., Kumvula, C., Chikosi, L., Mwale, M., \& Rosenberg, N. (2016). Contraceptive uptake after a couples counseling intervention with community health workers: a cluster randomized trial. Contraception, 94(4), 417.

Peraturan Menteri Kesehatan. (2017). Peraturan Menteri Kesehatan Republik Indonesia Nomor 28 Tahun 2017 Tentang Standar Pelayanan Minimal Bidang Kesehatan.

Pristiani, E., Junaid, J., \& Paridah, P. (2016). Hubungan Pengetahuan, Sikap, Dan Status Pekerjaan Ibu Balita Dengan Frekuensi Penimbangan Balita Ke Posyandu Di Wilayah Kerja Puskesmas Pamandati Kabupaten Konawe Selatan. Jurnal IImiah Mahasiswa Kesehatan Masyarakat Unsyiah, 1(2), 186849. 
Rahayu, D., Alimansur, M., \& Rinawati, F. (2017). Hubungan Antara Pengetahuan Dengan Pelaksanaan Sistem Lima Mejadi Posyandu Balita Kelurahan Ngronggo Kecamatan Kota Kota Kediri. Jurnal Ilmu Kesehatan, 1(1), 25.

Sari, D., \& Indarwati, L. (2012). HUBUNGAN PERILAKU MASA PUBER DENGAN PRESTASI BELAJAR DI SMP NEGERI 5 BOYOLALI Dewi Ginanjar Sari \& Lies Indarwati Akademi Kebidanan Estu Utomo Boyoalali. Jurnal Kebidanan, 4(1), 78-95.

Sheikh, N., Sultana, M., Ali, N., Akram, R., Mahumud, R., Asaduzzaman, M., \& Sarker, A. (2018). Coverage, Timelines, and Determinants of Incomplete Immunization in Bangladesh. Tropical Medicine and Infectious Disease, 3(3), 72.
Simanjuntak, M. (2015). Karakteristik Sosial Demografi dan Faktor Pendorong Peningkatan Kinerja Kader Posyandu. Jurnal Penyuluhan, 10(1), 49-58.

United Nations Children's Fund (UNICEF). (2004). The State of the World's Children.

Wahyuni, H. C., \& Hanum, S. M. F. (2018). Ibm Untuk Peningkatan Kualitas Layanan Posyandu Melalui Perbaikan Alat Timbang Balita. Jurnal ABDINUS: Jurnal Pengabdian Nusantara, 2(1), 7 .

WHO. (2016). Promotion Health, Promoting Sustainable Development.

WHO. (2017). Adolescer Development. 
This page itentionally left blank. 